Tomasz Duda

\title{
The St. Olav's Way - the origin, nature and trends in development of pilgrimage activity in Scandinavia
}

\begin{abstract}
In the Middle Ages the idea of pilgrimage reached Scandinavia, for a long time regarded as a permanent mainstay of pagan beliefs associated mainly with the traditions and culture of Nordic warriors - the Vikings. The prolonged and filled with many difficulties process of Christianization of northern Europe, over time developed a rapidly growing cult of St. Olav - a warrior, king and martyr of the Christian faith. Over nearly four hundred years, thousands of pilgrims embarked on pilgrimages to the tomb of the saint in Trondheim, making the Nidaros Cathedral the most important pilgrimage center in this part of Europe.

In 1997, the first section of the St. Olav's Way between Oslo and Trondheim was officially re-opened. After it has been signposted, described and promoted, as well as after it has been awarded with the title of European Cultural Route by the European Council in 2010, the St. Olav's Way has become one of the largest and most important pilgrimage routes in Europe. The present study is based on preliminary research conducted by the author on the St. Olav's Way in the last couple of years. Analysis of the available statistical data, as well as the opinions of the trail users themselves and its organizers as obtained by the author through social studies (surveys and direct interviews) allowed, however, to develop some preliminary research on the size and nature of pilgrimage movement along the routes of the St. Olav's Way.
\end{abstract}

Keywords: religious tourism, pilgrimage, Way of St. Olav, Norway, Scandinavia

\section{Introduction}

For over twenty years, a significant increase of interest in medieval pilgrimage routes that once existed in almost every region of the old continent has been observed in Europe. It is reflected, among others, in a clear increase in pilgrimage and tourist-religious movement along all the main routes, especially along the 
Way of St. James (to Santiago de Compostela in Spain), the Via Francigena (from Canterbury to Rome), the St. Olav's Way (to Trondheim in Norway), the Way of St. Martin (from Hungary to Tours in France for instance) or traditional routes to Jerusalem (Trono 2012, Mróz, Mróz 2013, Griffin, Raj 2014). Particularly popular are the Ways of St. James, making up the Europe's largest system of pilgrimage routes - Camino de Santiago. They were once the most important axes over which the faith, culture and Christian ideas spread to the furthest corners of the continent. Today they are an indisputable indicator of certain standards to which subsequent old pilgrimage routes being revitalised or recreated refer to.

Even in the Middle Ages the idea of pilgrimage also reached Scandinavia, for a long time regarded as a permanent mainstay of pagan beliefs associated mainly with the traditions and culture of Nordic warriors - the Vikings. The prolonged and filled with many difficulties process of Christianization of northern Europe, over time developed a rapidly growing cult of St. Olav - a warrior, king and martyr of the Christian faith. Over nearly four hundred years, thousands of pilgrims embarked on pilgrimages to the tomb of the saint in Trondheim, making the Nidaros Cathedral the most important pilgrimage center in this part of Europe.

Despite the expanding secularization of public life in Scandinavia and significant inhibition of pilgrimage movement (mainly due to the Reformation introduced in the sixteenth century and the progressive secularization of society), the work aiming at the reactivation of the historic way commenced in 1990, and seven years later, the first section of the St. Olav's Way between Oslo and Trondheim was officially opened. After it has been signposted, described and promoted, as well as after it has been awarded with the title of European Cultural Route by the European Council in 2010, the St. Olav's Way has become one of the largest and most important pilgrimage routes in Europe (next to the Camino de Santiago, the Via Francigena and the Way of St. Martin).

Both the Polish and the international (including Scandinavian) literature notes a significant lack of considerations relating to the pilgrimage movement or the wider religious tourism along the St. Olav's Way. On the one hand, it may prove the marginalization of the phenomenon in the context of the development of tourism in northern Europe and a strong orientation of the strategy towards active, natural tourism or even sightseeing, on the other hand the lack of interest may be explained with insufficient time for a development of pilgrimage wanderings to the tomb of the saint king from scratch. 
Some information about the St. Olav's Way may be found in few publications that appear the most often in the context of historical and archaeological research (Friedland 1981, Müller 2000, Anotnsson 2003, Kulesza 2005, Pranke 2009). An absolute leader within the domain of medieval pilgrimage (in historical perspective) is the international series of publications entitled: Studies in Medieval and Reformation Traditions, which periodically raises issues related to the history of Christianity and the pilgrimage movement in Scandinavia. However, the social, cultural and geographical aspects (in the context of touristic geography) associated with the St. Olav's Way are almost completely disregarded. Popularisation of the route has been undertaken by the Norwegian association Nasjonalt Pilegrimssenter, which also runs the website "pilegrimsleden.no". The association also issues informative publications and tourist guides. Since 2010, i.e since the year in which the St. Olav's Way has been officially recognized as the European Cultural Route of the European Council, Nasjonalt Pilegrimssenter has also been publishing annual statistical reports showing changes in the nature and intensity of the pilgrimage activity (or touristic, touristic and cultural) along the trail. Such data, along with the author's own observations and research carried out in pilgrims walking down the St. Olav's Way, contributed to the analysis of the pilgrim and tourist activity shown in this study, as well as its changes in relation to the intensity, structure and spatial development.

\section{The cult of St. Olav in Norway and beyond}

Christianization of northern Europe was an extremely difficult and lengthy process (it took nearly 200 years), which was mainly characterized by constant struggle and compromise between tradition and age-old beliefs and the new religion, often completely unknown. The adoption of the new faith by the Scandinavians was often associated often with simultaneous merging of Christian themes with those of pagan origin. On many occasions the baptism itself was merely a symbolic act, superficial and did not require any spiritual preparation (Pranke 2009). It was mainly the 'konungs' (regional kings) and 'jarls' (tribal ruler, representing the king in the field) who possessed the economic and military potential, were subject to the conversion process. Strongly divided points of view, as far as the matter of introduction of Christianity in Norway was concerned, largely hindered, however, a complete unification of the country under the rule of a single, strong 
sovereign. Great attachment to the traditions of pagan life and a strong dependence on ancient myths resulted in the situation, in which most of the local rulers did not even want to hear about the new religion. The first Christian king of the partly united Norway was Haakon the Good, who was baptized in England, and from there he brought missioners and a bishop into the country. Unfortunately, he was not able to provide security to the new priests, who quickly left Norway. Although there has been a strengthening of faith in the days of the King Olaf I Tryggvason, it is only since the time of his successor - Olaf II Haraldsson (the later saint) we can date the actual beginnings of a relatively permanent Christianity in Norway ${ }^{1}$.

Olaf Haraldsson was probably born in 995 in Ringerike. He was the son of a local king of Vestfold - Harald Grenske and great-grandson of the famous Harald Fairhair, the first unifier of Norway. Olaf, being the Viking, repeatedly despatched to the British Isles and remained on duty in Normandy, where he was baptised in the town of Rouen, in 1013 or 1014 . A year later, he was proclaimed the king of entire Norway, but because of his determination in the context of the introduction of Christianity, he came into a deteriorating conflict with the lords and local jarls, which eventually ended in the Battle of Stiklestad (Stiklestaðir) in 1030. King Olaf fell in the battle and was buried at the very site where it took place, near the village. With his death, the Saint Olaf was born. Just over a year later, in August 1031 the translatio (transfer of the body to the crypt in Nidaros, now Trondheim) took place, and the king was declared a saint ${ }^{2}$. Saint Olaf quickly became the patron of the whole of Norway, and his cult spread throughout Europe in a dizzying pace. This is confirmed by, among others, numerous churches erected and dedicated to the saint in the whole of Scandinavia and far beyond - from Iceland, via Scotland, England, Norway, Sweden up to Novgorod in Russia, Pomerania and the Baltic countries (Kvam 2008). In Norway itself the number of such temples exceeded 50, which was the second most popular choice of dedication next to the Blessed Virgin Mary (Fredriksen 2004). The legends and miracles, which began to appear for his cause, largely contributed

1 However, the views of Kulesza (2007) must be agreed with, who believes that nearly 35 years of reign of Olaf Tryggvason and Olaf Haraldsson constitutes far too short period in order to consider the new faith as being permanently enrooted in Norway.

2 While proclaiming the King Olaf a saint was carried out officially and with the approval of the bishopric of Bremen, his sainthood and canonization, however, have never been officially confirmed by Rome and the Pope. 
to the process of spreading of the cult. Olaf has also become a major patron of the Norwegian bishoprics - in Nidaros and Oslo, and further masses of pilgrims began arriving to his tomb.

The popularity of the saint was especially growing among merchants sailing the seas, belonging to the Hanseatic League particularly developed in the medieval times. It is thanks to them the cult of Olaf reached the Baltic cities, which over time have become important centers associated with the veneration given to the Norwegian king. The largest among them were for instance: Bruges, Rotterdam, Haarlem, Amsterdam, Maastricht, Münster, Bremen, Lübeck, Rostock, Stralsund, Greifswald, Visby, Elbląg, Gdańsk, Königsberg (Kaliningrad), Riga, Rewal (Tallinn) or Novgorod (Friedland 1981, Mroczko 1981). The Norwegian saint enjoyed a great popularity also in Pomerania (Pranke 2009), which for centuries laid in the center of interest of the Scandinavian Vikings and had numerous contacts with the Hanseatic merchants. In addition, the development of worship was supported by Cistercian monasteries there (brought to Pomerania from the Danish Esrum), Premonstratensian, the Franciscans and Dominicans, who had numerous possessions, monasteries and foundations in the Duchy of Pomerania (Piskorski et al. 1999).

Over several centuries the Saint Olaf became an icon of holiness, justice and fairness in the pantheon of the Norwegian kings. He became a symbol of the nation and the images presenting him as an enthroned sovereign in the crown holding an apple and an ax in his hands, can be found in almost every temple of Norway and neighboring countries. Olaf is also mentioned in the Norwegian national anthem, which says that "upon the country Olav painted with his blood the cross" ("Olav på det landet malte korset med sitt blod").

\section{Development and revitalization of pilgrimage routes to the tomb of king Olaf in Trondheim}

Shortly after the battle of Stiklestad in 1030 and the death of King Olav Haraldsson, Nidaros became one of the most popular pilgrimage destination across northern Europe. Hundreds of pilgrims appeared on trails and paths all over Scandinavia to wander (often for many days) to the saint's tomb in the Nidaros Cathedral (Nidarosdomen). They used mostly scarce (due to the topography of Norway and difficult accessibility of mountain ranges) communication 
routes, mostly led in vast and populated valleys. The widely available ways called at that time tjodvei (national trails) became the nucleus of permanent pilgrimage routes, today known as the St. Olav's Ways.

Pilgrims traveled frequently in groups, covering the daily distance of approximately $30 \mathrm{~km}$. To get to Nidaros, located on the fjord coastline in the central part of Norway (todays Trondheim), the travelers had to overcome formidable and often extremely difficult to cross mountain ranges (Dovrefjell, Jotunheim and Rondane), rivers and wetlands (crossed thanks to purposely placed wooden logs, the so-called. kavlebru). Stops were arranged at every 8-10 km, which facilitated recovery and allowed for feeding horses. These places were called the St. Olav's Fields (Olavsfeld). As time went by numerous inns and hostels emerged along the way - salehus (or small huts - hytte), in which pilgrims could stay overnight, and in which they often had only a fireplace and wooden bed at their disposal. The tradition also points out to a number of crosses, pilgrimage chapels and sacred wells and springs, which one could come across along all the routes of the St. Olav's Way.

Given the surface relief and the chances to reach Nidaros, as well as the presence of a few common trade routes functioning in the space (tjodvei), seven main pilgrimage routes to Nidaros evolved in the Middle Ages (today they are called the St. Olav's Ways). Their course is presented in the attached cartogram (Fig. 1). Those being:

a) Sea Route (Kystveien) (A) leading from southern Norway, the area of Oslo, as well as Denmark and the Baltic Sea countries, along the western coast of Norway strewn with thousands of islands, bays and fjords, directly to the port of Nidaros (now Trondheim);

b) The route through the valley of Gudbrand (Gudbrandsdalsleden) (B) - the most popular route, running from Oslo through the Gudbrandsdal Valley and Oppdal, Rondane and Dovrefjell massif in the direction of Trøndelag and Nidaros;

c) Østerdalen Way (Østerdalsleden) (C) - parallel to the Gudbrandsdalsleden route, led from the Hedmark region through the Østerdal valley to Nidaros;

d) Värmland-Trysil Way (D) - branch of the Østerdalsleden Way, that connected the Swedish region of Varmland with the proper Østerdalsleden Way (near the town of Trysil) and led away along the common tract to Nidaros;

e) Romboleden Way (E) - the oldest section of the St. Olav's Ways in Norway, leads from the areas of Sweden (Jämtland and Härjedalen), and combines tradition connected with St. Olav with the cult of Saint Brigid, popular in Sweden. 


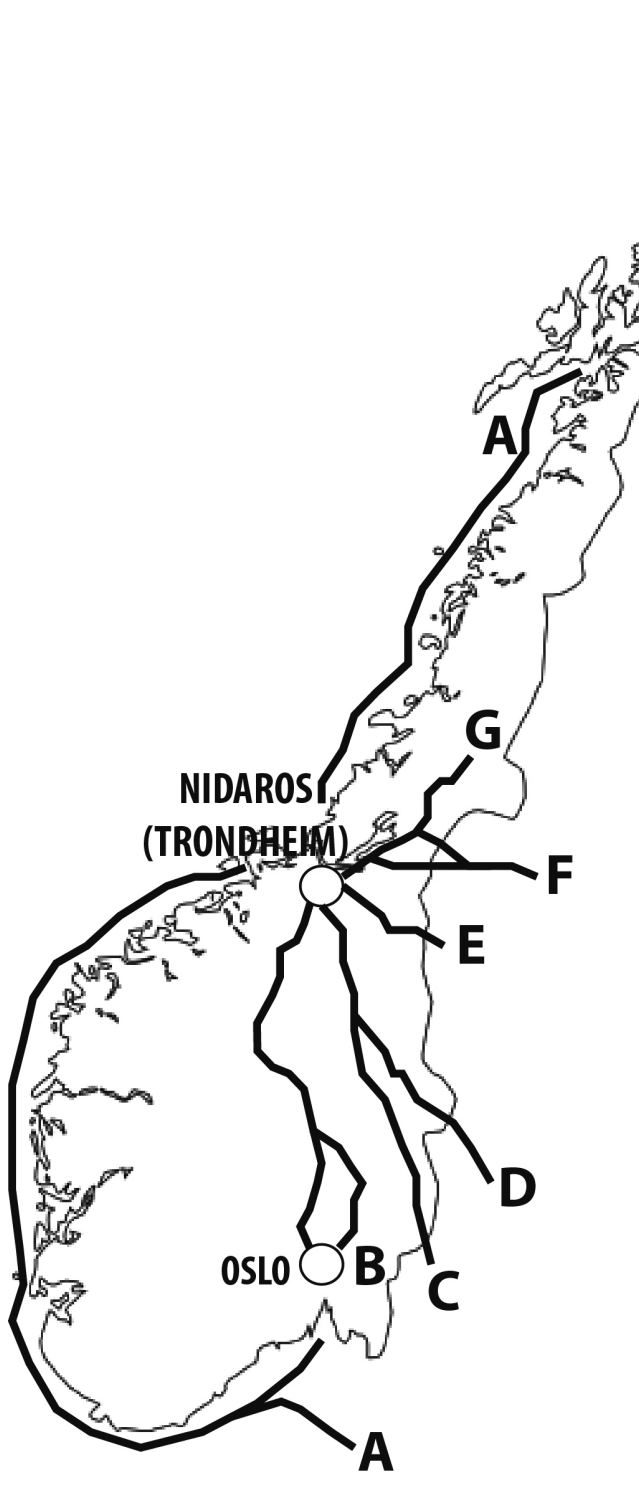

\section{WAYS OF ST.OLAV}
A - The coastal route (Kystleden)
B - Gudbrandsdalsleden
C - Østerdalsleden
D - Varmland-Trysil
E - Romboleden
F - St. Olavsleden
G - North Way (Nordleden)

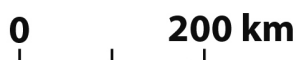

Fig. 1. Routes of pilgrimage ways to the tomb of St. Olaf in Trondheim, in the Middle Ages

Source: own study based on Arnulf Selnes 2008. 
f) St. Olav's Way (St. Olavsleden) (F) - one of the oldest routes of the St. Olav's trail, running along a historic tract, used by king Olav and his army to arrive in Norway to finally fight the battle of Stiklestad; the route connects the Baltic Sea coast in Selånger with the coast of the Norwegian Sea in Nidaros (Trondheim);

g) North Way (Nordleden) (G) - only a small part of it is officially marked - between the medieval church of Gløshaug in Grong and place of the historical battle of Stiklestad; in the past the way was used by the pilgrims traveling from distant regions of northern Norway.

All roads converged at one point - the square in front of the Nidaros Cathedral - the town that less than half a century following the death of Olav was called civitas Trondemnis (Trondheim). The town located at the river Nida (Nidelva) in less than one hundred years has become the most important center of pilgrimage throughout Scandinavia. In addition to the magnificent cathedral (Nidarosdomen), concealing the burial place of the holy king and the seat of the archbishopric, in Trondheim there were as many as 14 other churches providing shelter and caring for pilgrims who arrived to the city, including the St. Olav's church (the Franciscan monastery), St. Clement's church, St. Martin's church or the church of St. Nicholas. Also several religious orders were active there at the time, which erected their monasteries along the trail (such as the Franciscans and Dominicans). Each year, three up to seven thousand pilgrims arrived in the town, representing a multiple of its dwellers (in the Middle Ages Trondheim had a population of about 2500 permanent residents) (Jondell 2009).

Nidaros Cathedral was visited by pilgrims regardless of their age, social status or even wealth. Kings, the great ones, leaders and monks as well as ordinary people undertook the pilgrimage effort, while for the latter the way itself was no longer an end in itself. From Oslo the way would be made in approximately 25 days (643 km), although from Greenland, it took more than two months, including a long and difficult passage through the Atlantic Ocean (Duda 2014). Regardless of the taken route, the last day of the trip the pilgrims welcomed at the so-called Hill of Joy - mons gaudii (eg. in Feginsbrekka on the Gudbrandsdalsleden route or Evenstjønna on the Østerdalsleden route), where for the first time during their journey they had the opportunity to see their destination - the towers of the cathedral in Nidaros.

The pilgrimage to the tomb of St. Olav developed for more than 500 years. It ended almost definitely with the introduction of the reformation by the Danish 
kings. The cult of the saint was banned, many churches were destroyed, and considerable devastations took place in the very same Nidaros Cathedral. The pilgrim movement disappeared for many centuries. A true renaissance of the great medieval pilgrimage routes took place only in the last decade of the twentieth century (Jackowski, Soljan 2002, Jackowski 2003). Already in the 80s of the last century there was a sudden revival of pilgrimage activity along the Camino de Santiago routes (Wójtowicz 2011, Mróz et al. 2012), which became the inspiration for the creation and revitalization of old routes, often unused for centuries. Initial work aiming at the reconstruction of the historical St. Olav's Way commenced in 1990, and seven years later the first sections of the re-marked and prepared to handle the pilgrimage movement route were opened. The Østerdalsleden way from Skard ra to Trondheim and the Northern way from Grong to Stiklestad were revitalized as the first ones. Also the works related to staking-out and marking of the Gudbrandsdalsleden parts were commenced in the very same year (Oslo - Hamar section). This most preferable route of the St. Olav's Way was completed in its entirety in 1999, staking-out eventually $643 \mathrm{~km}$ from Oslo to Trondheim. Currently (as of 2016) the length of all designated historic routed to the tomb of the saint king is $2140 \mathrm{~km}^{3}$. Routes were marked with wooden posts with a distinctive logo - the Cross of St. Olav with the symbol of the tourist attraction in the background (severdighet). Along the Gudbrandsdalsleden also milestones were placed showing the distance to Nidaros and the symbol of the Way. The organisation of the trail and the use thereof has been arranged similarly to the Compostela model. Just like on the Ways of St. James pilgrims receive special passports (pilegrimpass), in which they collect stamps gathered along the way confirming the crossing of individual sections. After they have finished the trail (the minimum of 10 Norwegian miles - i.e. $100 \mathrm{~km}$ ), in the Nasjonalt Pilegrimssenter office in Trondheim, the bearers of completed passports receive commemorative personal confirmation of completion of pilgrimage, the so-called Olausbrevet (Letter of St. Olaf).

3 Some of the routes have been marked in the field by means of symbols, boards, guide posts and milestones (eg. the Gudbrandsdalsleden in its entirety and St. Olavsleden, partially Østerdalslenden and the North Way), while some parts have only been marked in information materials (on maps, in guides, and the routes intersection points). 


\section{Changes in size and structure of the pilgrim activity on routes of the St. Olav's way}

After many centuries of interruption caused by the aforesaid factors of political, religious and social nature, in the last several years there has been a clear interest in wandering to the tomb of St. Olaf. It emerged already in the 80 's of the $20^{\text {th }}$ century, slightly jumping on the bandwagon of the revival of pilgrimages to the holy places, particularly Santiago de Compostela. However, it seems that on the area of Scandinavia, it did not result out of spiritual needs, but to a large extent from the need of new forms of hiking and recreation activities. It was the form of an ever so popular style in this part of Europe, a philosophy even, so-called friluftsliv, which involves spending outdoors time (Gelter 2000). It should be noted, however, that the importance of Trondheim as the center of spiritual and religious Norway, part of the historical heritage of the country, is not subject to any dispute. Every year, to the Nidaros Cathedral arrives about half a million of tourists, many of which declare their motives being the religious and spiritual ones (as per Årsrapport Trondheim Kommune 2015).

When the work on the reactivation of the historic pilgrimage route commenced in 1990, the large-scale promotional campaign largely familiarised the Scandinavians with the concept of pilgrimage and the religious significance of the medieval Way. This contributed to the establishment of a number of associations, the goal of which was to promote pilgrimage and encouraging undertaking the spiritual journey. Following the Camino de Santiago model, the historic tract was subject to restoration and signposting activities and first pilgrims turned up on the trail. Today, the scale of the pilgrim movement on the routes put into service is difficult to be estimated, as the professional registration of pilgrims has only been carried out since the establishment of the National Pilgrimage Center in 2010 and merely in the most popular section of the trail of the St. Olav's Way - Gudbrandsdalsleden.

The analysis of changes in the size and structure of pilgrimage activity was based on data, published every year (since 2010) by the National Pilgrimage Center (Nasjonalt Pilegrimssenter - NPS) affiliated by the Nidaros Cathedral in Trondheim, and regional Pilgrimage Centers (Pilegrimssenter) in Oslo and Hamar. The reports are published in Norwegian and mainly contain information on the number of certificates issued confirming the completion of the trail (the so-called Letter of St. Olaf), the number of pilgrims allowed on the trail in Oslo (based on 
the registration of passports pilgrim), and the ethnic structure of pilgrims coming off the trail. In addition, information obtained directly from the NPS employees through direct interviews and from the pilgrims themselves receiving the certificate in Trondheim - by administering a short questionnaire to them.

Gudbrandsdalsleden was the first section, which was revitalized and opened to pilgrims in 1997. Thanks to a great promotion, good quality signposting and numerous publications and guides, this section of the St. Olav's Way is the most popular. In 2015 it was covered by $67 \%$ of the total number of pilgrims to Nidaros (Fig. 2). The second place was taken by the historical route St. Olavsleden, which was selected by $12 \%$ of pilgrims, many of whom (40\%) covered its entire length, from the shores of the Baltic Sea in Sweden $(564 \mathrm{~km})$. A similar popularity may be attributed to the trail parallel to the one from Oslo - Østerdalsleden (in 2015 it's been chosen by $10 \%$ of the pilgrims). Other ways are characterized by negligible interest (North Way - 7\%, Romboleden - 3\%, and branch to Trysil - merely $1 \%)$, mainly for reasons of difficult accessibility and poor signage.

From 2010 onwards there is a dramatic increase in the number of pilgrims receiving the Letter of St. Olaf - confirmation of covering of $100 \mathrm{~km}$ on foot or $200 \mathrm{~km}$ by bike along any section of Ways. The number was 165 in 2010 and within the following five years the figure increased almost five times (in 2015 the Certificate was awarded to 774 persons) (Fig. 3A, 3B).

Apparent, substantial and unusual increase in the number of confirmations issued in 2012 has been a result of the presence of a large organised group of more than 160 pilgrims from Spain, who, being an association and fans of the Ways of St. James, decided to cover the trail leading to the tomb of St. Olaf. An interesting fact is also the preparation of special diplomas for the ones pilgriming the St. Olav's Way in 2012, regardless of the number of kilometers covered (therefore independent of obtaining the Letter of St. Olaf). Such diplomas were sold in 115 copies in 2012, 285 in the following year to reach the number of 597 thereafter (Fig. 3B).

The difficult passage through the massif of the Scandinavian Mountains, as well as vast marsh areas, devoid of any infrastructure, result in the situation, in which not everyone undertaking the pilgrimage eventually reached Trondheim (on average 40-50\%). This trend is based on data obtained from the point of issue of pilgrim passports (pilegrimpass). 300 pilgrims were officially registered in 2010 (165 received the Letter - which makes up 55\%) (Fig. 3A). A year later, out of 600 pilgrims $60 \%$ reached the destination, in $2012-64 \%$, in $2013-42 \%$ 


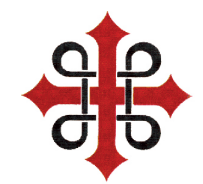

W AYS OF ST.OLAV

TO NIDAROS / TRONDHEIM

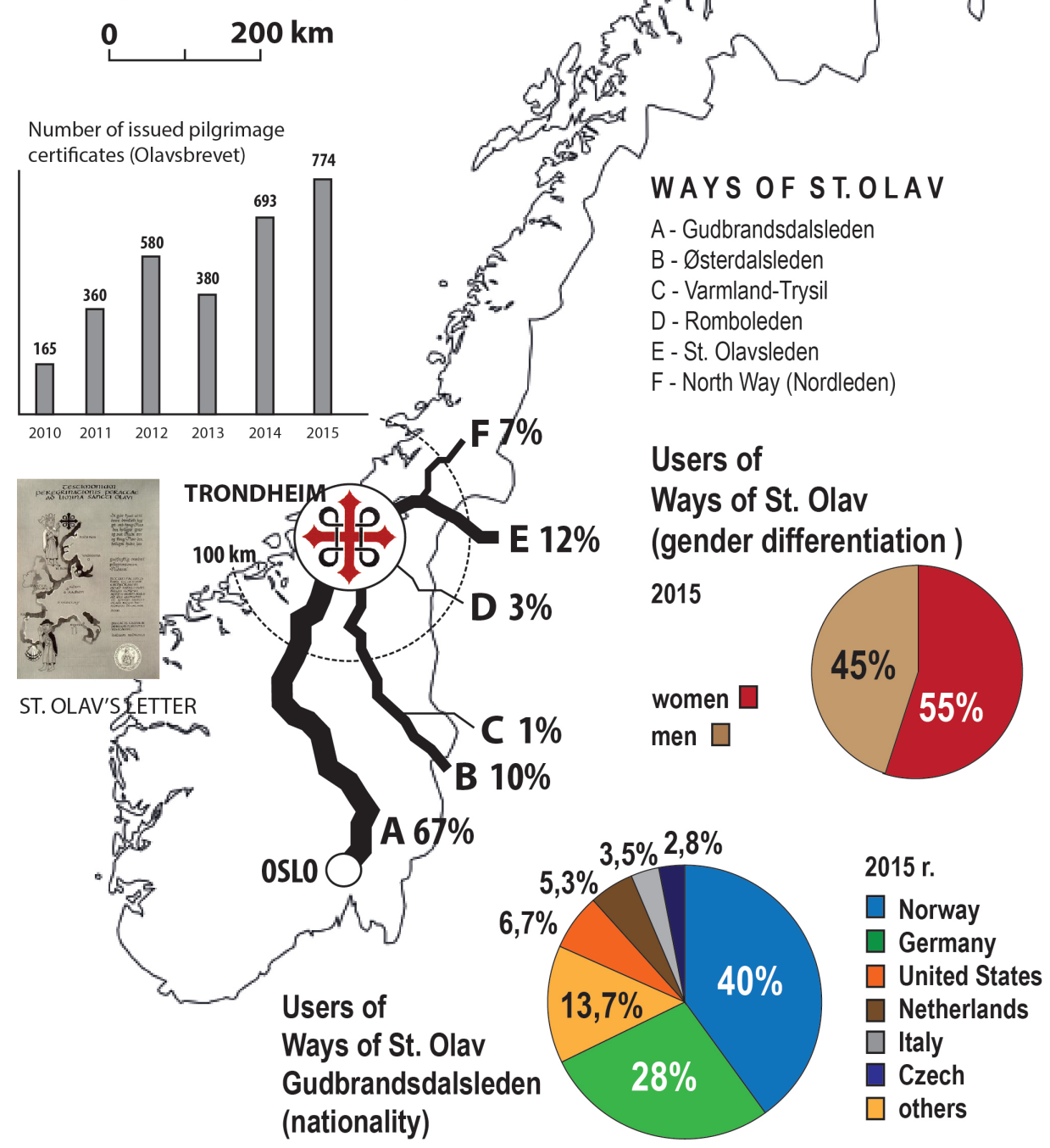

Fig. 2. Statistics summary for pilgrim activity on the Ways of St. Olav in 2015 Source: own study. 

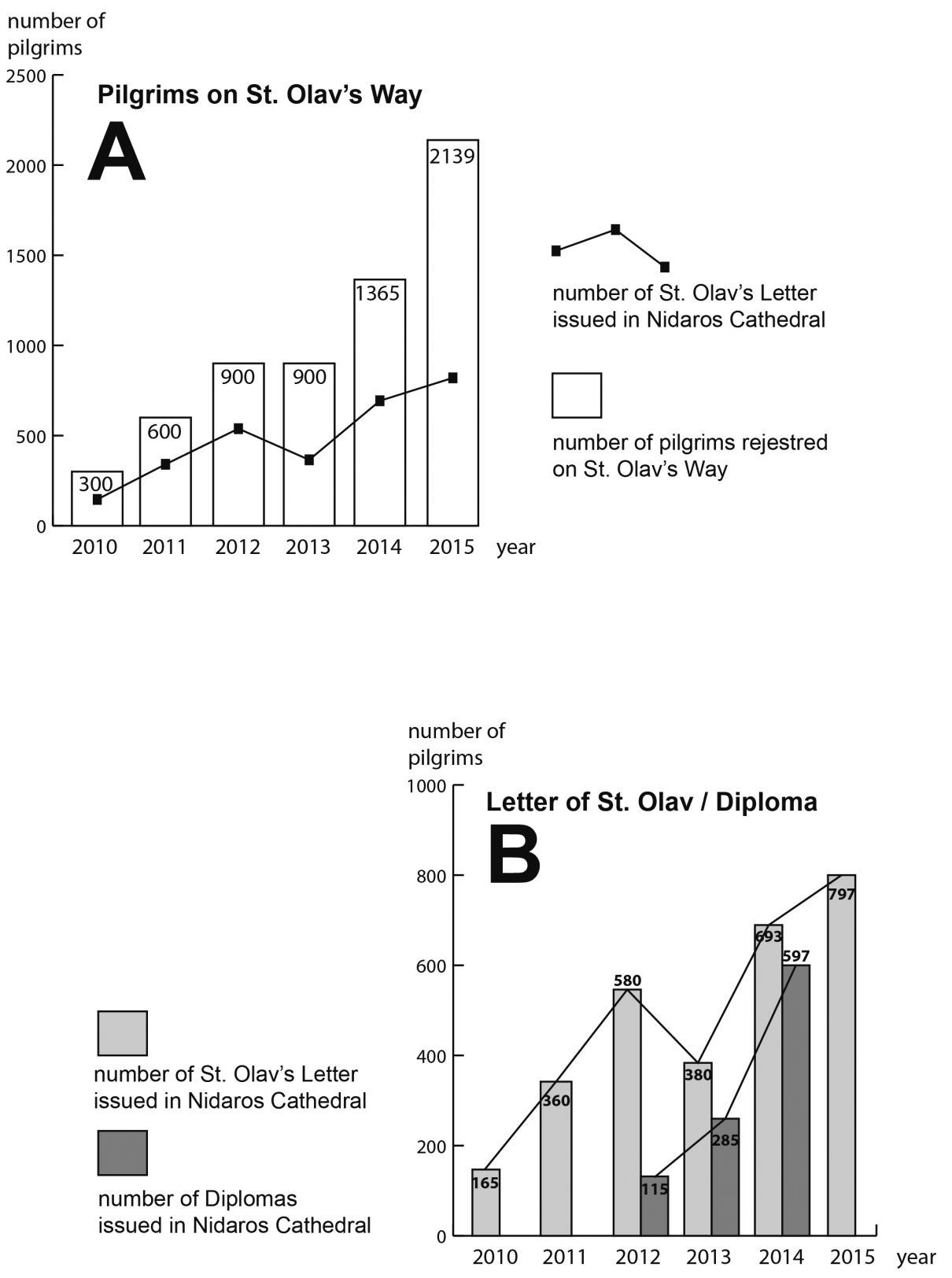

Fig. 3. The number of pilgrims (tourists) recorded on routes of Way of St. Olaf (A) and the number of issued Letters of St. Olaf and certificates (diploma) confirming the passage route $(B)$

Source: own study. 
(a significant decrease explained by the financial crisis in Europe), in 2014 - 51\% and in 2015 - $37 \%$ (a decrease resulting rather from the vast number of registered pilgrims - 2139).

The pilgrimage activity along the most popular section of the St. Olav's Way - the Gudbrandsdalsleden, looks particularly interesting. Statistical research concerning this route are mainly carried out by Pilgrimage Centre in Oslo (Pilegrimssenter Oslo) and, albeit not systematically, a similar centre in Hamar.

The scarcest information is from 2010. The intention to leave Oslo to hit the trail by registering at the Centre and purchase a passport was declared by only eight people this year (Fig. 4). Because the total number of registered pilgrims at all St. Olav's Ways was 300 people in 2010, the conclusion is that the vast majority wandered only parts of the route, relatively close to the destination. This is evidenced by the number of overnight stays in pilgrimage hostels - e.g. in Dale Gudbrand located in the central part of the trail 20 people were checked in for the night, while in the mountain region of Dovre, less than $150 \mathrm{~km}$ from Trondheim - that number came up to 408 people (Tab. 1).

Apparent changes are already observed in 2011. As many as 282 people visited the Pilgrimage Centre in Oslo, of which 54\% were foreigners. 78 people hit the trail eventually from the Norwegian capital (Fig. 4). Out of these, as many as 53 people came from outside Norway, which accounts for $68 \%$ of all pilgrims travelling from Oslo. The largest group was made up of German-speaking hikers, mainly the Germans (47\% of all foreigners). Such ethnic diversity results from, among others, cultural similarities between Germans and Scandinavians, being protestant communities with a long tradition of wandering. Like the previous year, as we approach

Table 1. Number of people staying overnight in pilgrimage shelters along Gudbrandsdalsleden route of Way of St. Olaf, in 2010-2015

\begin{tabular}{|l|r|r|r|r|r|r|}
\hline & 2010 & 2011 & 2012 & 2013 & 2014 & 2015 \\
\hline Hamar Pilegrimssenter & - & - & - & 70 & 105 & 185 \\
\hline Dale Gudbrand & 20 & 96 & 122 & 98 & 139 & 212 \\
\hline Nidaros Pilegrimsgård & - & 536 & 823 & 648 & 939 & 932 \\
\hline Dovre (cały region) & 408 & 1853 & 2547 & 2684 & 3276 & 3820 \\
\hline
\end{tabular}

Source: own study based on: Årsrapport - Pilegrimssenter Oslo. 


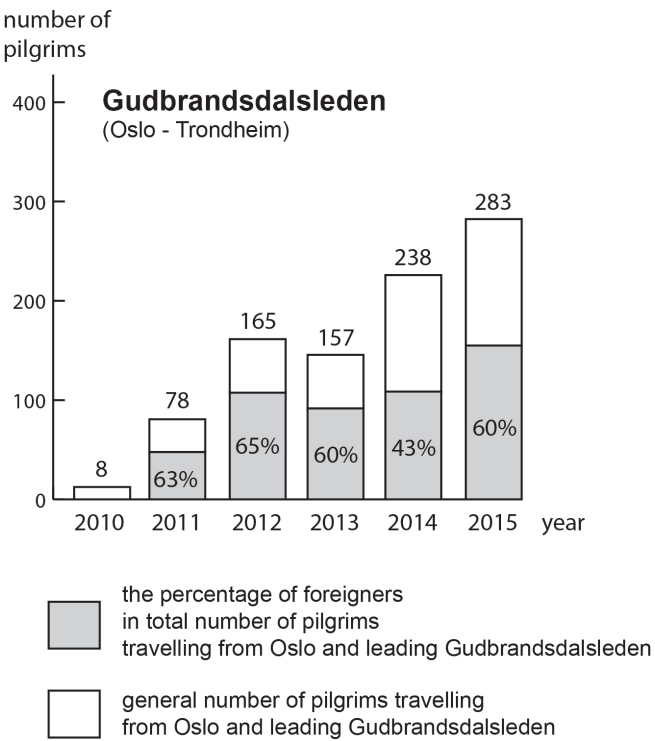

Fig. 4. The number of pilgrims (including the percentage of foreigners) wandering Gudbrandsdalsleden trail of Way of St. Olaf from Oslo to Trondheim

Source: own study. the destination (Nidaros Cathedral in Trondheim) the number of overnight stays in hostels increases (Tab.1). A huge number of them in the area of Dovre - 1,853 people is particularly remarking. It is worth noting at this point that the pilgrim hostels in places attractive for tourists are also used by hikers, traversing mountain trails. Some of them, encouraged by others, however, decide to make the short stretch of pilgrimage way, which joins the Dovre massif with Trondheim.

2012 is the year when the Gudbrandsdalsleden trail was hit by pilgrims from the record-breaking high number of countries - 20. As many as 165 people set off from Oslo, which an increase by $112 \%$ compared to the previous year (Fig. 4). Among

the hikers, 35.2\% were Norwegians (58 persons) and 64.8\% of foreigners (107 persons). Traditionally, the biggest group were Germans (27.9\%), followed by the Dutchmen (7.3\%), Americans and Poles (4.2\% - 7 persons), Italians (3.6\%), Australians (3.0\%) and representatives of such countries as: Argentina, Austria, Canada, Denmark, England, Finland, France, Latvia, Spain, Sweden, Switzerland, the Czech Republic, Ukraine and Hungary. The large representation of pilgrims from outside Europe (even from distant Australia) is also noteworthy.

The economic crisis that affected the world and Europe in 2013 has also taken its tool on the pilgrimage routes. Although there was no drastic decline in interest in St. Olav's Ways however, comparing to the year of 2012, fewer people hit the route. 157 persons set off from Oslo towards Trondheim (a decrease by $4.8 \%$ compared to the previous year) (Fig.4). Approximately $40 \%$ of them were Norwegians (62 persons). The largest group of foreigners came from Germany 
( $28 \%$ - 44 persons), the Netherlands ( $8.2 \%-13$ persons), Sweden, Poland and Canada (3.2\% per each nation -5 persons respectively), Denmark $(2.5 \%-4$ persons) and then Australia, Belgium, Brazil (the first time), England, France, Ireland, Italy, Scotland, Spain, Switzerland, Sweden, the USA and Austria (1-2 persons). The number of overnight stays in pilgrim shelters also clearly decreased (Tab.1). The slight increase was only recorded in Dovre region, where the mountain trails were visited by a lot of Norwegians, not interested in a journey towards the grave of their saint patron.

The increasing trend returned to the pilgrimage routes of Norway in 2014. However, the ethnic structure of the wandering persons changed dramatically. Out of the 238 persons that turned up on the trail from Oslo, as many as 127 (i.e. 57\%) were Norwegians. The still struggling with the crisis foreigners represented countries such as: Germany ( $24 \%$ - 56 persons), Italy ( $7.6 \%-18$ persons), the USA ( $4.2 \%$ - 10 persons), the Netherlands ( $2.5 \%-6$ persons), Australia ( $2.1 \%-5$ persons), Poland ( $0.8 \%-2$ persons) and Belgium, England, France, Hungary and Austria.

The last registered year for which the data was developed (at the time of the article the data for 2016 has not yet published as it is usually published in MarchApril) in many ways turned out to be a record-breaking. 797 persons received the Letter of St. Olaf at the Nidaros Cathedral (Fig. 3B). As many as 2,139 persons registered as pilgrims (received the pilgrim passport) (Fig. 3A), and 283 persons hit the trail from Oslo (Fig.4). Almost 40\% of them were Norwegians (112 persons) and quite new and exotic nationalities appeared among foreigners (including the Japanese and Koreans). The largest group (except for the Norwegians) was formed by Germans ( $28 \%$ - 79 persons), Americans (6.7\% - 19 persons), the Dutchmen (5.3\% - 15 persons), Italians (3.5\% - 10 persons), Bohemians (2,8\% - 8 persons), Swiss, French, Danes and English (5-7 persons) and the representatives of Australia, Finland, the Faroe Islands, Poland, Slovakia, Spain, Sweden, Austria, Japan and Korea (1-2 persons per nationality).

\section{Directions of development of religious tourism in Scandinavia}

Can the revival and development of pilgrimage activity to Nidaros be said to exist on the basis of the period of six years in which the marked St. Olav's 
Way remains in operation? Certainly the above reports indicate the continued trend of significant (if not rapid) growth in the number of people covering the route to the tomb of the saint king (Fig. 3A). Thanks to the huge popularity of the Ways of St. James across Europe also other medieval pilgrimage tracts are gaining interest, also in marginal areas - away from the main pilgrimage routes and the well-known centers of worship. This also applies to Scandinavia, as indicated by the number of visitors to NPS in Oslo, Hamar and Trondheim (in 2015 - 1,350 persons).

However, new or newly revived old spaces of religious tourism increasingly emerge in areas hitherto neglected and generally conceived of as unattractive, as well as devoid of pilgrimage and tourist-religious activity (Duda, Ostrowski 2012, Duda 2016). Using forgotten or little known local (or regional) historical heritage and traditions, they significantly activate the region, and above all, meet the religious and cultural needs of pilgrims who cannot afford to satisfy them away from their own place of residency. The area of Scandinavia (especially Norway), however, seems to be unique in this respect. Centuries-old traditions of hiking, wandering along mountain trails and spending time outdoors are simply incorporated in the nature of Norwegian society (Gelter 2000). The region is characterised by a high tourist attractiveness, both in terms of nature (a unique one, in largely not touched by the civilization), and culture (mostly the legacy of the Vikings). Reactivation of a medieval pilgrimage route here is a kind of a filling-gap process, associated rather with the need for the development of the cultural heritage tourism and with the need to gain a new perspective on own cultural identity (including the religious one).

This does not certainly imply the total disappearance of the phenomena of pilgrimage understood as sacrum. Two different ways of development of this phenomena are being observed along the St. Olav's Ways - on the one hand it is an act of a strictly religious nature (pilgrimage), on the other hand it is a wandering of a religious and cognitive nature (developed over time into the broader concept of religious tourism) and even of the religious and recreational one. Around the strictly defined, and determining the concept of pilgrimage sacrum zone, the well developed and increasingly important profanum zone has emerged, including all the elements that have contributed to the perception of pilgrimage, also as the tourism phenomena (Jackowski 1996, Dallen, Olsen 2006, Wójtowicz 2011, Mikos von Rohrscheidt 2013, Duda 2016).

The National Pilgrimage Centre formed in 2010 at the Nidaros Cathedral in Trondheim, in accordance with the activities set forth in its statute, is also involved 
in organizing the development of spirituality and the wider considered religious tourism in different regions of Norway. ${ }^{4}$ Since 2011 the NPS regional office in Oslo organizes numerous cultural and religious events, devoted to the pilgrimage and to the very figure of St. Olaf. A large part of such meetings has the form of organized wanderings (over a long and short distance), which every year are becoming more popular (Tab. 2). In 2015, in out of the 220 pilgrimages organised by NPS (mostly 1-3-day-long along different sections of Gudbrandsdalsleden and Østerdalsleden routes) participated a record-breaking number of 4838 people, representing $67 \%$ of all persons participating in various events organised by NPS. The growing importance of local, short and organized pilgrimage hikes is also reflected in the surveys and direct interviews with the participants and organizers of such events. They show that the vast majority of Norwegians (and other Scandinavians) identifies with the need for spiritual growth, which is based on the figure of St. Olaf, but above reaching the tomb of the latter they prefer to experience the sense of community within the group, short marches

Table 2. Statistical summary of tourist and religious events, (including hiking pilgrimages) organized on the trail Way of St. Olaf, in 2010-2015

\begin{tabular}{|l|l|l|l|l|l|l|}
\hline & 2010 & 2011 & 2012 & 2013 & 2014 & 2015 \\
\hline $\begin{array}{l}\text { the total number of tourist and religious } \\
\text { events connected with the cult } \\
\text { of St. Olaf }\end{array}$ & no data & 86 & no data & 106 & 185 & 255 \\
\hline $\begin{array}{l}\text { the number of people participating } \\
\text { in events }\end{array}$ & no data & 5832 & 3990 & 3682 & 5950 & 7174 \\
\hline $\begin{array}{l}\text { the total number of pilgrim wanderings } \\
\text { (long- and short-distance) organized } \\
\text { on the trail of Way of St. Olaf }\end{array}$ & no data & 48 & 61 & 87 & 151 & 192 \\
\hline $\begin{array}{l}\text { the number of people participating } \\
\text { in wanderings organized on the trail } \\
\text { of Way of St. Olaf }\end{array}$ & no data & 3081 & 2818 & 2461 & 4279 & 4838 \\
\hline
\end{tabular}

Source: own study based on: Årsrapport - Pilegrimssenter Oslo.

4 As per the statute of NPS - Nasjonalt Pilegrimssenter. Evaluering av NPS og de regionale sentrene, 2015. 
accompanied with joint prayers and discussions. While observing this trend we are encouraged to say that this revival of local pilgrimage and ecumenical meetings will be a future determinant of the development of religious tourism activity in this part of Europe.

\section{Conclusions}

Revitalization, marking and adapting the St. Olav's Ways for operation became the cause of a significant revival of and interest in the pilgrim movement in Norway and the neighboring countries. It is difficult to indicate its size shortly after the official opening of the route (1997), as the National Pilgrimage Centre began publishing and making the reports and statistics widely available only in 2010 . The sale of pilgrim passports and issue of the completion of the trail Certificates (the so-called Letter of St. Olaf) also commenced at that time. It should be emphasized that the present study is based on preliminary research conducted by the author on the St. Olav's Way in the last couple of years. The data on the social or professional differentiation of the pilgrims for instance, their motivation while deciding to undertake the pilgrimage, as well as the methods of covering the Way is still missing.

Analysis of the available statistical data, as well as the opinions of the trail users themselves and its organizers as obtained by the author through social studies (surveys and direct interviews) allowed, however, to develop some preliminary research on the size and nature of pilgrimage movement along the routes of the St. Olav's Way. Although detailed data come from Gudbradnsdalsleden only - one of the most frequented branch of the trail, due to its importance, to a large extent it is representative for the entirety. While in 2010-2012, the pilgrims basically chose just that well-marked route, since 2013 an increasing percentage has been choosing alternative routes leading to Trondheim. This is partly connected with the desire to cover the Way once more, using a different route this time round. Still, nearly 70\% of wanderers from Oslo each year, along the Gunbrandsdal valley and Dovrefjell massif. Furthermore, this route has the best management and the largest number of structures attractive from the religious and cultural tourism perspective. The research also showed that the medieval tradition of pilgrimage and religious trek to the Nidaros Cathedral are becoming increasingly popular in the recent years. This is applicable both to the Norwegians and pilgrims (tourists) coming from other European countries 
and even other continents (North America, South America, Australia and Asia). More and more people receive the Letter of St. Olaf, which confirms that they have at least covered $100 \mathrm{~km}$ on foot. This shows the clear revival of the idea of pilgrimage that contribute to the growth of a sense of identity with elements of religious heritage of this part of Europe.

\section{References}

Anotnsson H., 2003, The cult of the St. Ólafr in the eleventh century and Kiev and Rus, „Middelalderforum”,1-2, p. 143-160.

Brink S., 2013, Myth and Ritual in Pre-Christian Scandinavian Landscape, [in:] S. Walaker Nordeide, S. Brink (ed.), Sacred Sites and Holy Places. Exploring the Sacralization of Landscape Through Time and Space, Studies in Early Middle Ages, Brepols, 11, p. 20-32.

Collins-Kreiner N., 2010, The geography of pilgrimage and tourism: Transformations and implications of applied geography, „Applied Geography”, 30, p. 153-164.

Dallen J.T., Olsen D., 2006, Tourism, Religion \& Spiritual Journeys, Routledge, London-New York.

Duda T., Ostrowski P., 2012, Revitalization of the pilgrimage routes as a chance of development of new tourism spaces on the example of West Pomerania region (NW Poland), EJHTR International Conference, Santiago de Compostela.

Duda T., 2014, Norwegia, Wydawnictwo ExpressMap, Warszawa.

Duda T., 2016, Kształtowanie się przestrzeni wspótczesnej turystyki religijnej na obszarach marginalnych ( $w$ oddaleniu od znaczacych centrów religijnych i wielkich szlaków pielgrzymkowych), na przykładzie Pomorza Zachodniego, [in:] J. Mokras-Grabowska, J. Latosińska (ed.), Kultura i turystyka - sacrum i profanum, ROTWL, Łódź, p. 119-136.

Ekroll Ø., 1995, Nidaros Cathedral and the Archbishop's Palace, NCRWP, Trondheim. Friedland K., 1981, Sankt Olav als Schutzpatron nordeuropäischer Kaufleute, „Acta Visbyensia”, 57 (2), p. 17-26.

Gelter H., 2000, Friluftsliv: The Scandinavian Philosophy of Putdoor Life, „Canadian Journal of Environmental Education", 5, p. 77-95.

Jackowski A. (ed.), 1996, Przestrzeń i sacrum, geografia kultury w Polsce i jej przemiany $w$ okresie od XVII do XX wieku na przykładzie ośrodków kultu i migracji pielgrzymkowych, IGUJ, Kraków. 
Jackowski A., 2003, Święta przestrzeń świata. Podstawy geografii religii, Wydawnictwo Uniwersytetu Jagiellońskiego, Kraków.

Jackowski A., Sołjan I. (red.), 2002, Szlaki pielgrzymkowe Europy, Wydawnictwo Znak, Kraków.

Jondell E., 2009, The Pilgrim City by Nidelven, [in:] In the Pilgrim Way to Trondheim, Tapir Academic Press, Trondheim, p. 34-40.

Kulesza P., 2007, Normanowie a chrześcijaństwo. Recepcja nowej wiary w Skandynawii w IX i X wieku, Wrocław-Racibórz.

Kvam B.O., 2009, Olav Churches in Europe, [in:] In the Pilgrim Way to Trondheim, Tapir Academic Press, Trondheim, p. 48-50.

Langslet L.R., 2009, The Saint King, [in:] In the Pilgrim Way to Trondheim, Tapir Academic Press, Trondheim, p. 9-14.

Majewski M., Rębkowski M., Simiński R., 2016, Pielgrzymki pomorskie $w$ średniowieczu. Stan i perspektywy badań, „Przegląd Zachodniopomorski”, 31 (60), 1, p. 129-168.

Mikos von Rohrscheidt A., 2013, Religion as a subject of cognitive interest to tourists. Analysis of the phenomenon and products on offer forcultural-religious tourism, „Turystyka Kulturowa”, 5, p. 5-19.

Mróz F., Mróz Ł., 2013, Nowe trendy w turystyce religijnej, [in:] R. Pawlusiński (ed.), Współczesne uwarunkowania i problemy rozwoju turystyki, p. 105-119.

Müller O., 2000, Święty Olaf król Norwegii, Warszawa.

Nilsson M., Tesfahuney M., 2016, Performing the "post-secular" in Santiago de Compostela, „Annals of Tourism Research”, 57, p. 18-30.

Orzechowska-Kowalska K., 2014, Europejskie Szlaki Kulturowe Europy w Polsce, Rozprawy Naukowe AWF we Wrocławiu, Wrocław, 46, p. 112-118.

Piskorski J., (ed.), 1999, Pomorze Zachodnie poprzez wieki, Wydawnictwo Zamek Książąt Pomorskich, Szczecin.

Pranke P., 2009, Droga Olafa Haraldssona do świętości - przyczynek do badań nad zagadnieniem kultu świętego Olafa $w$ kontekście hipotez interpretacyjnych dotyczacych znalezisk toporków miniaturowych, „Pomorania Antiqua”, 22, p. 61-75.

Rinschede G., 1992, Forms of Religious Tourism, „Annals of Tourism Research”, 19, p. 51-67.

Selnes A., 2009, At Sea and on Land, [in:] In the Pilgrim Way to Trondheim, Tapir Academic Press, Trondheim, p. 16-18.

Trono A., 2012, Travelling to the East on the Via Francigena through art, cultures and history, Edizioni Esperdi, Lecce. 
Wójtowicz M., 2011, Przekształcenia ruchu pielgrzymkowego do Santiago de Compostela w latach 1989-2010, „Peregrinus Cracoviensis”, 22, p. 313-333.

\section{Web pages}

Annual Rapports of Pilgrimage Activity on the Routes of St. Olav Way in Norway: 2010: http://oslo.pilegrimsleden.no/uploads/documents/Aarsrapport2010.pdf 2011: http://oslo.pilegrimsleden.no/uploads/documents/Aarsrapport2011.pdf 2012: http://oslo.pilegrimsleden.no/uploads/documents/Aarsrapport2012.pdf 2013: http://oslo.pilegrimsleden.no/uploads/documents/Aarsrapport2013.pdf, http://nasjonaltpilegrimssenter.no/dynamic/upload/bilder/Dokumenter/Årsrapport-2013-Nasjonalt-pilegrimssenter.pdf

2014: http://oslo.pilegrimsleden.no/uploads/documents/Aarsrapport2014.pdf http://nasjonaltpilegrimssenter.no/dynamic/upload/bilder/Dokumenter/Årsrapport-2014for-Nasjonalt-pilegrimssenter.pdf

2015 http://oslo.pilegrimsleden.no/uploads/documents/Aarsrapport_2015_godkjent_l.pdf

Tomasz Duda, Ph.D.

Department of Earth Sciences

University of Szczecin, Poland 
